\title{
Cytotoxic Activity of Crude Extracts and Fractions from Irvingia malayana
}

\author{
Ari Widiyantoro ${ }^{1}$, Thamrin Usman ${ }^{2}$, Edy Meiyanto ${ }^{3}$, Sabirin Matsjeh $^{4}$ \\ ${ }^{I}$ Ph.D Student, Department of Chemistry, Faculty of Mathematic and Natural Sciences, Gadjah Mada \\ University, Yogyakarta, Indonesia \\ ${ }^{2}$ Department of Chemistry, Faculty of Mathematic and Natural Sciences, Tanjungpura University, Pontianak, \\ Indonesia \\ ${ }^{3}$ Faculty of Pharmacy, Gadjah Mada University, Yogyakarta, Indonesia \\ ${ }^{4}$ Department of Chemistry, Faculty of Mathematic and Natural Sciences, Gadjah Mada University, \\ Yogyakarta, Indonesia
}

\begin{abstract}
Irvingia malayana has been utilized for traditional medicine in West Kalimantan, Indonesia.The aim of this research is to detect cytotoxic activity of extract of Irvingia malayana. The extraction with methanol and partition by variated eluen polarity. This extraction produced methanol extract, $n$-hexane fraction, methylene chloride fraction, ethylacetate fraction and methanol fraction. Cytotoxic test using MTT assay method was done to each extract and fraction. Cell viability profiles produced from MTT assay showed that methanolic extract, the other fractions (n-hexane, metylen chloride, ethylacetate and methanol) from bark of Irvingia malayana decrease HeLa cells viability compare to control cells in the concentration dependent manners with $I_{50}$ of 59 , $92,30,22$, and $33 \mu \mathrm{g} / \mathrm{mL}$ respectively. The strongest cytotoxic activity was showed by ethylacetate fraction of bark of Irvingia malayana, but methylen chloride fraction of root of Irvingia malayana also potencial to find bioactive compound against Hela cell line.
\end{abstract}

Keywords - Irvingia malayana, cytotoxic activity, crude extracts, fractions, HeLa cell line

\section{INTRODUCTION}

Irvingia malayana is a plant in the Simaroubaceae family. It is distributed in Southeast Asia e.i Indonesia, Thailand, Vietnam, Cambodia and Laos. This plant spesies is widely distributed in Sumatera and Kalimantan, Indonesia. West Kalimantan people used stem bark extract this plant as traditional medicine. In Sambas and Ketapang District, extract of Irvingia malayana used it to cure cancer and malaria, especially extract of bark. How to use it is to soak 3-5 pieces bark of Irvingia malayana in one cup of hot water and then allowed to stand for 5 minutes to drinked as cancer and malaria drugs.

This plant have been reported containing compounds as antimalaria [1], [2], antimutagenic [3], antiinflamation [4] and antifeedant [5]. Widely studied plant parts are leaves, wood and seeds. This research investigates the cytotoxic activity of all parts of the plant against HeLa cells.

Based on literature studies, the biological activity of plant extracts of Irvingia malayana against HeLa cells showed that ethanol crude extract of the leaves of Irvingia malayana have cytotoxic activity ( $\left.\mathrm{IC}_{50}\right) \quad 11.7 \mu \mathrm{g} / \mathrm{mL}$ and methanol fraction $\left(\mathrm{IC}_{50}\right) 14.8 \mu \mathrm{g} / \mathrm{mL}$ against HeLa cells. While the fraction of cyclohexane and methylene chloride showed no cytotoxic activity against HeLa cells. This literature has not revealed what compounds is contained in the leaves of Irvingia malayana which is cytotoxic against HeLa cells [1].

Several chemical compounds have been isolated from various plant parts of Irvingia malayana. Chemical compounds have been isolated from the wood of Irvingia malayana are 2-hydroxy-3, 2 ', 6'-trimethoxy-4'-(8', 9'-epoxy-7'hydroxypropyl)-5-ethenal-biphenyl); 9-hydroxy-7-methoxy-8-(4'-hydroxy-3'-methoxyphenyl)-4-hydroxy-3- methoxy phenylpropane; 3-hydroxy -1 - (4-hydroxy- 3-methoxyphenyl)-1-propanone; caffeic aldehyde; ferulaldehyde; $n$-hexacosyl ferulate; $7 \beta$-hydroxy- $\beta$-sitosterol; $\beta$-sitosterol- $\beta$-D-glucoside; glutinol and oleanoic acid [6]. While the methanol extract of the stem bark of Irvingia malayana have been isolated betulinic acid which showed cytotoxic activity and antiangiogenic [7]. Others secondary metabolites that friedelin; friedelinol; 3,3',4'-tri-O-methylellagic acid; methyl 3,4,5trihydroxybenzoate; 3,3',4'-tri-O-methylellagic-xyloside- $\beta$-glucoside; 3,3'-di-O-methylellagic acid-4- $\beta$-acid-6"-acetoxy-4glucoside; 3,3',4'-tri-O-methylellagic acid-4-glucopyranoside; $\beta 5,7,4^{\prime}$-trihydroxyflavone-8-C-glucopyranoside and $\beta 5,7,3^{\prime}, 4^{\prime}$ tetrahydroxyflavone-8-C-glucopyranoside-7-O-linkage also have been isolated from Irvingia malayana. The isolated $\beta 5,3^{\prime}, 4$ '-trihydroxyflavone-6-C- compounds were tested for cytotoxicity and anti-HIV reverse transcriptase. Compound 3,3',4'-tri-O-methylellagic acid showed activities against several human cell lines i.e. KB, KB-V(+VLB), KB-V(-VLB), Lu-1 and ZR-75-1 [8]. 


\subsection{Material}

\section{MATERIALS AND METHODS}

Stem bark, bark, leaves and root of Irvingia malayana were used as sample in this research. It was taken from Palung Mountain National Park, Ketapang, West Kalimantan, Indonesia. Accuracy of sample species was determinated in Herbarium Bogoriense, LIPI, Indonesia. Sample was dried in room temperature for a week. Then, the sample was grinded and filtered (use filter $60 \mathrm{mesh}$ ). The powder of the sample is extracted by maceration. The chemistry materials that used are organic solvent, silica gel G 60 (230-400 mesh), silica gel G60 (70-230 mesh), TLC plates silica gel 60 F254 (Merck), and carcinoma cell of human servics (HeLa cell line)

\subsubsection{Extraction}

\subsection{Methods}

The powder of stem bark of Irvingia malayana $(2 \mathrm{~kg})$ was macerated with methanol $80 \%$ in room temperature ( $4 \times 24$ hours). Extracts are filtered and the filtrate is collected. Residu is remaceration by added new methanol. All the filtrate are collected and evaporated.Methanol extract of the sample was extracted (partition) by $n$-hexane, methylene chloride and ethylacetate. All fraction were evaporated, then the activity test will done by MTT assay. The same procedure was also carried out on samples of bark (2 kg), leaves (1 kg) and root $(2 \mathrm{~kg})$ of Irvingia malayana

\subsubsection{Cell culture}

To growth HeLa cell (ATCC CCI 2.1) collection of Cancer Chemoprevention Research Centre, Faculty of Pharmacy, Gadjah Mada University, it can do in the first day. Media that used is DMEM with 10\% PBS and Penstrep. Cell concentration is $1.10^{-4} / \mathrm{mL}$, used 12 source, each volume is $4 \mathrm{~mL}$. Then, cell will incubated in incubator (temperature $37^{\circ} \mathrm{C}$ ). In second day, cell is washed and added with extract and fraction. Cell washing by take $2 \mathrm{~mL}$ from each source then added by $2 \mathrm{~mL}$ from new media (two source as control), and added by 2 $\mathrm{mL}$ extract and fraction 125, 250,500, and $750 \mathrm{ppm}$ in concentration that has dissolved use culture media completely. Incubation is continued in $37^{\circ} \mathrm{C}$ until fifth day. In fifth day, tripsination is done. After that, we will count total of the cell that still alive. It used count room Neubauer under the microscope.

\subsubsection{Viability of Cell}

Viability of cells was measured by the MTT assay, which gives the concentration at which $50 \%$ of the cells remains viable after any extract and fraction treatment $\left(\mathrm{IC}_{50}\right)$. In this assay, MTT is converted to a blue formazan dye by mitochondrial enzymes in actively respiring but not necessarily proliferating cells. The intensity of the color formed can be correlated to untreated controls to obtain the $\mathrm{IC}_{50}$ value by reading the absorbance at $590 \mathrm{~nm}$. Cancer cells were seeded with various concentrations of the test compounds in a 96-well plate in a total volume of $200 \mu \mathrm{L}$ of medium. Sterile MTT (25 mL of $5 \mathrm{mg} \mathrm{mL}-1$ in PBS) was added to each well, and the plates were covered in foil and incubated at $37{ }^{\circ} \mathrm{C}$. After $3 \mathrm{~h}, 100 \mu \mathrm{L}$ of extraction buffer consisting of $20 \%$ SDS dissolved in a dimethylformamide/water $(1: 1, \mathrm{v} / \mathrm{v})$ solution at $\mathrm{pH} 4.0$ was added. Blue colour formation was measured at $590 \mathrm{~nm}$ with a Dynatech MRX microplate reader. The percentage of cells surviving was determined by comparing the absorbance of the solutions recovered from the treated cells with that of the control cells.

\section{RESULTS AND DISCUSSION}

Powdered of stem bark ( $2 \mathrm{~kg}$ ) of Irvingia malayana was extracted with methanol then to partition with $n$-hexane, methylene chloride and ethylacetate, yielding $120.3 \mathrm{~g} \mathrm{MeOH}$ extract, $12.2 \mathrm{~g} n$-hexane fraction, $23.5 \mathrm{~g}$ methylene chloride fraction, 50.2 ethylacetate fraction, and $25.6 \mathrm{~g}$ methanol fraction. While the bark $(2 \mathrm{~kg}) \mathrm{of}$ Irvingia malayana was extracted with methanol then to partition with $n$-hexane, methylene chloride and ethylacetate, yielding $130.5 \mathrm{~g} \mathrm{MeOH}$ extract, $13.6 \mathrm{~g} n$-hexane fraction, $24.1 \mathrm{~g}$ methylene chloride fraction, 52.1 ethylacetate fraction, and $27.2 \mathrm{~g}$ methanol fraction. Leaves $(1 \mathrm{~kg})$ of Irvingia malayana was extracted with methanol then to partition with $n$-hexane, methylene chloride and ethylacetate, yielding $70.5 \mathrm{~g} \mathrm{MeOH}$ extract, $6.3 \mathrm{~g} n$-hexane fraction, $10.2 \mathrm{~g}$ methylene chloride fraction, 20.2 ethylacetate fraction, and $11.9 \mathrm{~g}$ methanol fraction. Root $(2 \mathrm{~kg}$ ) of Irvingia malayana was extracted with methanol then to partition with $n$-hexane, methylene chloride and ethylacetate, yielding $118.9 \mathrm{~g} \mathrm{MeOH}$ extract, $13.1 \mathrm{~g} n$-hexane fraction, $22.5 \mathrm{~g}$ methylene chloride fraction, 49.3 ethylacetate fraction, and $23.9 \mathrm{~g}$ methanol fraction.

These activities were analyzed by monitoring cell viability of treated and untreated cells by their reduction of the tetrazolium substrate, MTT. Cytotoxity test showed $\mathrm{IC}_{50}$ of ethylacetate fraction of bark of Irvingia malayana was good activity than the others fraction and extract. Specifically of bark, cytotoxic activity have been reported before in proceeding [9]. 
Table 1. $\mathrm{IC}_{50}$ Cytotoxity against HeLa Cell (MTT assay)

\begin{tabular}{cc}
\hline Bark of Irvingia malayana & $\mathbf{I C}_{\mathbf{5 0}}(\boldsymbol{\mu g} / \mathbf{m L})$ \\
\hline Methanol Extract & 59 \\
$n$-Hexane Fraction & 92 \\
Methylene Chloride Fraction & 30 \\
Ethylacetate Fraction & 22 \\
Methanol Fraction & 33 \\
\hline
\end{tabular}

Table 2. IC $_{50}$ Cytotoxity against HeLa Cell (MTT assay)

\begin{tabular}{cc}
\hline $\begin{array}{c}\text { Stem Bark of } \\
\text { Irvingia malayana }\end{array}$ & $\mathbf{I C}_{\mathbf{5 0}}(\boldsymbol{\mu g} / \mathbf{m L})$ \\
\hline Methanol Extract & - \\
$n$-Hexane Fraction & 211 \\
Methylene Chloride Fraction & 162 \\
Ethylacetate Fraction & - \\
Methanol Fraction & 3161 \\
& \\
\hline
\end{tabular}

Table 3. IC $_{50}$ Cytotoxity against HeLa Cell (MTT assay)

\begin{tabular}{cc}
\hline Root of Irvingia malayana & $\mathbf{I C}_{\mathbf{5 0}}(\boldsymbol{\mu g} / \mathbf{m L})$ \\
\hline Methanol Extract & - \\
$n$-Hexane Fraction & 172 \\
Methylene Chloride Fraction & 70 \\
Ethylacetate Fraction & 593 \\
Methanol Fraction & - \\
\hline
\end{tabular}

Table 4. $\mathrm{IC}_{50}$ Cytotoxity against HeLa Cell (MTT assay)

\begin{tabular}{cc}
\hline $\begin{array}{c}\text { Leaves of } \\
\text { Irvingia malayana }\end{array}$ & $\mathbf{I C}_{\mathbf{5 0}}(\boldsymbol{\mu g} / \mathbf{m L})$ \\
\hline Methanol Extract & - \\
$n$-Hexane Fraction & 125 \\
Methylene Chloride Fraction & 325 \\
Ethylacetate Fraction & 201 \\
Methanol Fraction & 600 \\
\hline
\end{tabular}

Profiles obtained from cell viability MTT test showed that the methanolic extract and fractions (nhexane, methylene chloride, ethyl acetate, and methanol) of bark of Irvingia malayana in general may decrease the viability of cells HeLa cells compared with controls. Given cytotoxic effect is the effect depends on the level concentration of sample where the greater concentration of sample so the greater the levels cytotoxic effect. Inhibitory activity shown by the largest cell viability ethyl acetate fraction of bark of Irvingia malayana. Active compounds contained in the bark of Irvingia malayana is estimated to have the potential chemopreventive pretty good views of its value IC50 $(<100 \mu \mathrm{g} / \mathrm{mL})$ 


\section{CONCLUSION}

Ethylacetate fraction from stem bark of Irvingia malayana showed highest activity and potential to find bioactive compound againts HeLa cell line

\section{Acknowledgements}

We are grateful to Cancer Chemoprevention Research Centre, Faculty of Pharmacy, Gadjah Mada University, Yogyakarta Indonesia for cytotoxic test and the Directorate Higher Education, Ministry of Education and Culture, Republic of Indonesia for foundation this research by BPPS Programme

\section{REFERENCES}

[1] Pouplin. J. N. and Tran.H., 2007. Antimalarial and citotoxic activities of ethnopharmacologically selected medical plants from South Vietnam, J. of Ethnopharm. 109(2),417-427

[2] Praptiwi and Chairul. 2008. The effect of pauh kijang (Irvingia malayana Oliv. ex. A. Benn) in decreasing parasetimia percentage in mice infected with Plasmodium berghei. Biodiversitas.9. 96-98

[3] Nakahara, K., Roy. M. K., Alzoreky. N. S., and Thalang. N. V. 2002. Inventory of indegenous plants and minor crops in Thailand based on bioactivities, $9^{\text {th }}$ JIRCAS International Symposium, 135-139

[4] Widiyantoro, A., Destiarti, L., Kusharyanti, I., Supardi, Halim, D.G., Niwick and Willianti, V. 2012. Antiinflamation activity of bioactive compound from bark of Irvingia malayana against Rattus norvegicus induced by carrageenan, J. Kaunia, VII (2) :118-126

[5] Widiyantoro, A., Kustiati, and Usman, T. 2006. Isolation and characterization of antifeedant compound from ethylacetate fraction of stem bark of Irvingia malayana, J. Agripura, 4 (2) : 523-529

[6] Mitsunaga, K., Ouyang, Y., Koike, K., Sakamoto, Y., Ohmoto, T. and Nikaido, T.. 1996. Phenolic constituents of Irvingia malayana, Natural Medicines, 50 (5), 325-327

[7] Ng, K.W., Salhimi, S.M., Majid, A.M.S.A and Chan, K.L.2010. Antiangiogenic and cytotoxic studies of some medicinal plants, Planta Med., 76 : 935-940

[8] Jaipetch, T. 1999. Chemical constituen of Irvingia malayana and Clausena excavata.Ph.D thesis. Faculty of Graduate Studies, Mahidol University

[9] Kusharyanti, Widiyantoro, A., Maryati, and Meiyanto, E. 2008. Cytotoxic activity of bark extract of Irvingia malayana, Proceeding of XVI ISFI Congress, Yogyakarta 